\title{
POLA HIDUP KOMUNITAS GUA HUNIAN PRASEJARAH KAWASAN KARST BLORA
}

\author{
Indah Asikin Nurani \\ Agus Tri Hascharyo
}

\begin{abstract}
Blora limestone region is an important area where several prehistoric sites, occupied continuously during the Late Pleistocene to Early Holocene, are discovered. The Pleistocene sites are found in the southeast part of the Blora regency and the early Holocene sites are located in the District of Todanan, in the westem part of the regency. One of the most interesting sites situated in this area is the Kidang cave. It is the only limestone cave which shows traces of human occupation in this area. This paper will discuss about the possible adaptation as well as occupation patterns in Kidang Cave.
\end{abstract}

Key words: Gua Kidang, musim basah, musim kering, moluska, tulang

\section{PENDAHULUAN}

Kabupaten Blora merupakan wilayah penting dalam mengungkap budaya masa prasejarah, khususnya Kala Plestosen hingga awal Holosen. Sebagaimana diketahui, di daerah ini pernah ditemukan fosil rangka Elephas yang utuh, tepatnya di Sunggun dekat situs Ngandong di perbatasan Blora - Ngawi. Situs Ngandong sendiri merupakan situs manusia purba, tempat ditemukannya fosil-fosil Homo soloensis dengan beberapa artefak tulang dan batu (Simanjuntak, 1980). Selain Ngandong, di daerah ini juga terdapat situs manusia purba lainnya yaitu situs Jigar dan Kuwung yang berada di sebelah utara Ngandong. Kedua situs ini secara kronologis memiliki pertanggalan yang lebih muda dari pada situs Ngandong, namun ketiganya merupakan situs manusia purba Kala Plestosen.

Tulisan ini memang tidak dimaksudkan untuk membahas keempat situs tersebut, tetapi mencoba memberikan gambaran keberadaan situssitus yang lebih muda di daerah yang sama. Situs-situs tersebut berupa gua (cave) dan ceruk (rockshelter) dari awal Kala Holosen. Para penghuni situs itu diperkirakan tidak lagi mengembara namun sudah lebih menetap. Pertanyaan penelitian yang ingin dijawab adalah: apakah budaya hunian

* Peneliti Balai Arkeologi Yogyakarta

* Pengajar Jurusan Arkeologi, Fakultas IImu Budaya, UGM

Berkala Arkeologi Tafun XXX Edisi $\mathcal{N}_{0.1}$ / Mei 2010 
gua merupakan kelanjutan dari budaya manusia purba yang fosilnya ditemukan keempat situs tersebut di atas.

Manusia masa prasejarah, khususnya pada awal Kala Holosen, yang bertempat tinggal di gua-gua atau ceruk mempertahankan hidupnya dengan sangat bergantung pada ketersediaan sumberdaya di lingkungan alam sekitamya. Salah satunya dengan cara memanfaatkan gua dan ceruk untuk tempat tinggal mereka. Namun, manusia saat itu tentu mempunyai berbagai pertimbangan dalam memanfaatkan gua atau ceruk sebagai tempat tinggal. Mereka tidak melakukannya secara serampangan saja. Hal tersebut ditunjukkan dengan kenyataan bahwa tidak semua gua atau ceruk dimanfaatkan sebagai tempat bermukim. Dari aspek keletakannya, manusia saat itu cenderung memilih lokasi gua atau ceruk pada daerah-daerah yang menyediakan kebutuhan pokoknya, seperti sumber bahan makanan yang dianggap menguntungkan dari segi subsistensinya. Sebaliknya mereka tidak akan menempati daerah yang miskin sumber makanan, tandus, penuh bahaya, tidak sehat, atau sulit dari jangkauan baik dalam komunikasi maupun transportasi dengan daerah lain. Untuk keperluan hidupnya, mereka juga membuat perkakas dari bahan yang tersedia di lingkungan sekitarnya seperti batu, tulang, tanduk, cangkang moluska, dan kayu (Heekeren, 1972; Soejono, 1984; Simanjuntak, 1999). Dengan demikian, ketersediaan sumberdaya lingkungan akan sangat menentukan corak perkembangan teknologi yang diterapkan dalam pembuatan alat.

Sesungguhnya, penelitian gua-gua di Jawa, khususnya Jawa Timur, telah dilakukan oleh beberapa peneliti asing seperti L.J.C van Es, P.V van Stein Callenfels, W.J.A Willems, dan H.R van Heekeren yang berhasil mengungkap sejumlah situs gua di Kabupaten Ponorogo, Situbondo, Pacitan, Jember, Tuban, dan Bojonegoro. Penelitian tersebut lebih bersifat eksploratif untuk menjajagi potensi arkeologis gua-gua hunian di Jawa (Heekeren, 1972). Sementara itu, Balai Arkeologi Yogyakarta telah melakukan penelitian tematis selama 5 tahap pada himpunan gua di Kabupaten Jember dengan fokus pada studi spasial melalui kajian arkeologi ruang. Hasil penelitian pada himpunan gua di Kabupaten Jember terutama di perbukitan karst Watangan menunjukkan bahwa gua-gua yang dihuni manusia prasejarah ternyata memiliki fungsi sendiri-sendiri sesuai dengan kebutuhan komunitasnya. Misalnya, ada gua untuk dapur, gua untuk kubur, dan gua untuk pembuatan alat (Nurani dan Hascharyo, 2000). Selain itu, penelitian selama 2 tahap juga telah dilakukan pada himpunan gua di Kabupaten Bojonegoro. Hasil penelitian pada gua-gua di Dander, Bojonegoro, menunjukkan sangat terbatasnya data arkeologis di situs tersebut, bahkan tidak ada lapisan budaya yang cukup berarti (Nurani, 1999). Selanjutnya, selama 3 tahap pernah pula dilakukan penelitian pada himpunan gua di Sampung, Ponorogo. Hasil penelitian menunjukkan bahwa komunitas prasejarah di kawasan ini menggunakan satu gua induk (Gua Lawa) yang dimanfaatkan untuk berbagai fungsi dan dikelilingi ceruk-ceruk yang dimanfaatkan untuk aktivitas pendukung. Umumnya, gua pendukung difungsikan sebagai pembuatan alat batu (Nurani, 2002). Kajian terakhir 
adalah penelitian pada wilayah perbatasan Situbondo - Bondowoso. Himpunan gua di daerah ini sebagian besar merupakan gua yang pembentukannya pada batuan beku, bukan batuan kapur. Hasil penelitian menunjukkan di gua-gua tersebut tidak banyak ditemukan sisa-sisa aktivitas manusia (baik artefak maupun ekofak). Hanya terdapat dua gua yang memiliki indikasi hunian yaitu Gua Petpuruh (di daerah batuan kapur) dan Gua Pertapan (di daerah batuan beku). Sementara itu, Puslitbang Arkenas juga melakukan penelitian serupa di kawasan karst Gunung Sewu. Hasilnya menunjukkan bahwa gua-gua yang diteliti dimanfaatkan untuk berbagai fungsi, yaitu untuk aktivitas pembuatan peralatan baik peralatan dari batu, cangkang moluska maupun tulang, maupun untuk dapur, kubur, dan aktivitas sehari-hari lainnya (Simanjuntak, 1999).

Berdasarkan hasil kajian arkeologi ruang pada berbagai himpunan gua, dapat diketahui bahwa masing-masing himpunan gua memiliki karakter sendiri-sendiri. Selain itu, lokasi himpunan gua menunjukkan adanya dua lokasi yang secara geografis dekat dengan pantai dan himpunan gua yang berlokasi jauh dari pantai atau daerah pedalaman. Kedua lokasi himpunan gua tersebut menunjukkan karakter tersendiri berdasarkan data yang ditemukan. Himpunan gua yang berlokasi jauh dari pantai atau di daerah pedalaman memiliki temuan yang cenderung didominasi oleh alat dari batu (litik) daripada alat dari cangkang moluska. Adapun himpunan gua di daerah pantai temuan peralatannya cenderung didominasi alat-alat dari cangkang moluska daripada alat batu (Nurani, 2006).

Dalam kajian Arkeologi ruang (spatial archaeology) dikenal adanya tingkat keruangan yang meliputi skala mikro, skala meso atau semi mikro, dan skala makro (Clarke, 1977; Mundardjito, 1990). Sementara itu Parson membagi kajian keruangan dalam dua tingkatan yaitu tingkat komunitas (dalam hal ini direpresentasikan oleh situs) dan tingkat zonal yang dapat menunjukkan interaksi antarkomunitas dalam suatu kawasan (Soebroto, 1983). Terkait dengan kajian permukiman gua, ketiga skala ruang menurut Clarke dapat disamakan dengan satu unit gua untuk skala mikro, satu himpunan gua dalam satu kabupaten untuk skala meso atau semi mikro, dan beberapa himpunan gua dalam satu kawasan perbukitan karst Jawa untuk skala makro. Apabila mengikuti tingkat keruangan yang dikemukakan oleh Parson, maka tingkat komunitas dapat disejajarkan dengan satu himpunan gua dalam satu kabupaten, sedangkan tingkat zonal disejajarkan dengan himpunan gua dalam satu kawasan bukit karst.

Berdasarkan konsep arkeologi ruang tersebut, kajian ruang pada skala mikro akan dititikberatkan pada aspek-aspek yang berkaitan dengan pengaturan atau pola tata ruang yang tersedia dalam suatu gua untuk keperluan aktivitas manusia penghuninya. Selanjutnya, dengan mengintegrasikan hasil kajian pola tata ruang skala mikro akan dapat diketahui pola semi mikro (meso). Hal ini disebabkan karena pemanfaatan gua hunian mencerminkan suatu aktivitas micro settlement penghuninya, sedangkan dari aktivitas beberapa micro settlement tersebut akan tercermin aktivitas pada tingkat komunitas. Lebih luas lagi, dari kajian berbagai pola 
komunitas akan dapat diketahui pola zonal (skala makro) yang menunjukkan hubungan dan interaksi antarkomunitas. Lebih lanjut dapat dilihat bagan kerangka pikir yang mendasari penelitian dengan pendekatan arkeologi ruang sebagaimana dijelaskan di atas.

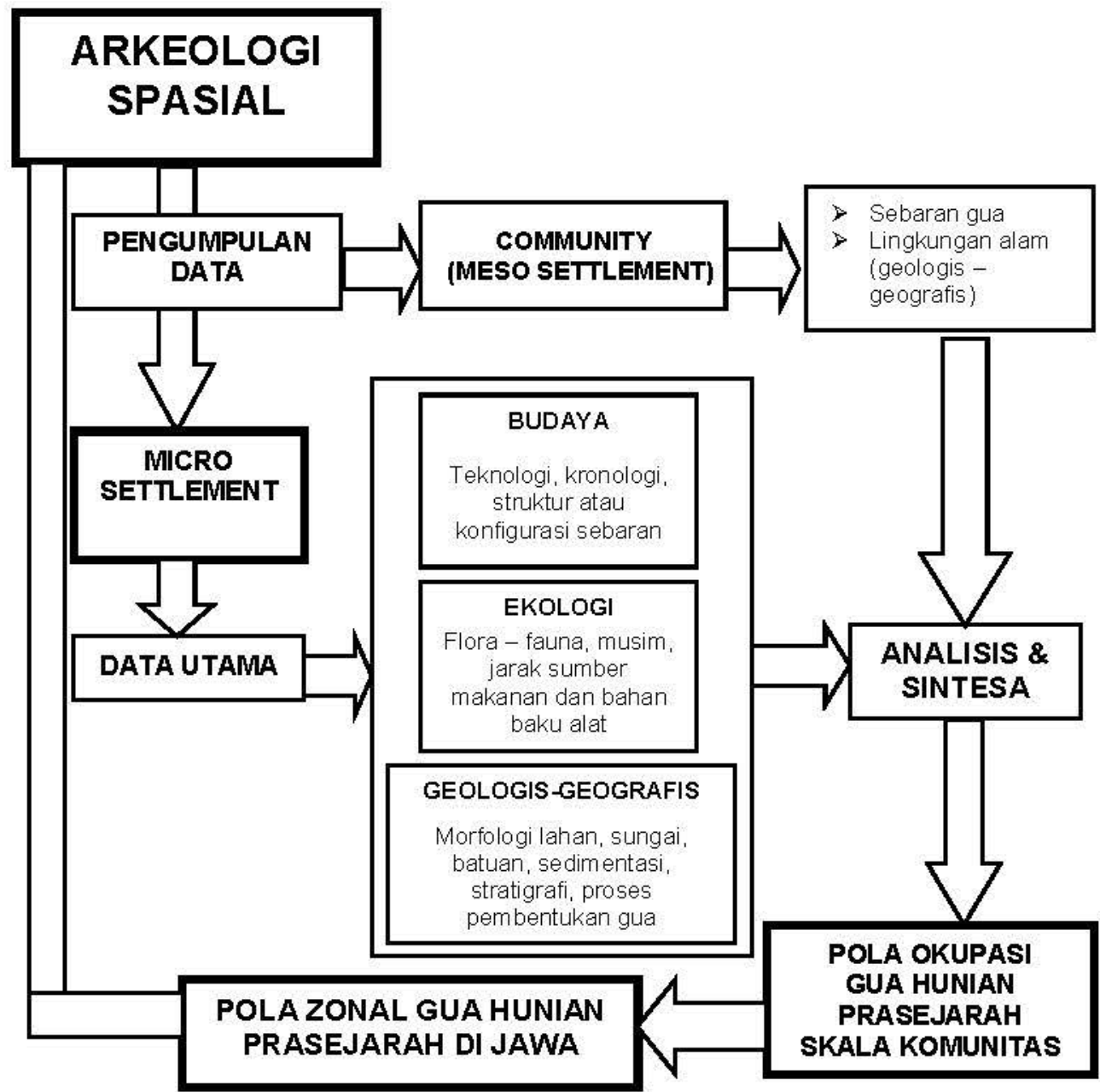

Berdasarkan penjelasan di atas serta hasil penelitian dari beberapa himpunan gua di kawasan karst yang ada di Pulau Jawa, tulisan ini akan mencoba mengungkap pola hidup komunitas gua yang diterapkan pada himpunan gua di kawasan karst kabupaten Blora. Adapun pertanyaan penelitian yang ingin dijawab adalah sebagai berikut.

1. Bagaimana pola hidup komunitas gua kawasan karst Blora?

2. Bagaimana pola adaptasi manusia penghuni gua masa prasejarah di kawasan karst Blora?

Namun, harus diakui data untuk menjawab pertanyaan penelitian di atas masih sangat terbatas. Satu-satunya situs yang terbukti mengandung 
data arkeologi yang dapat diandalkan hanyalah Gua Kidang. Karena itu, hasil penelitian yang dapat dikemukakan di sini tentu masih bersifat sementara.

\section{GUA KIDANG}

Penelitian Balai Arkeologi Yogyakarta yang difokuskan pada kawasan karst Kabupaten Blora, Jawa Tengah, telah dilaksanakan selama 4 (empat) tahap yaitu tahun $2005,2006,2009$, dan 2010. Pada tahap I dan II penelitian difokuskan pada survei gua-gua di kawasan karst Blora, sedangkan pada tahap III dan IV difokuskan pada ekskavasi di Gua Kidang. Dari hasil penelitian selama empat tahap tersebut telah dapat disimpulkan bahwa gua-gua di kawasan karst Blora ini sebagian besar tidak layak dihuni, jika dilihat dari perspektif arkeologis. Dari perspektif ini, biasanya kelayakan hunian suatu gua dinilai berdasarkan pada morfologi gua, sirkulasi udara, masuknya sinar matahari, dan temuan permukaan. Hasil survei eksploratif di kawasan karst Blora yang meliputi empat kecamatan yaitu di Kecamatan Todanan (11 gua), Jepon (4 gua), Bokorejo (1 gua), dan Kradenan (1 gua) menunjukkan bahwa satu-satunya gua yang secara arkeologis potensial hanyalah Gua Kidang (Nurani dan Yuwono, 2008).

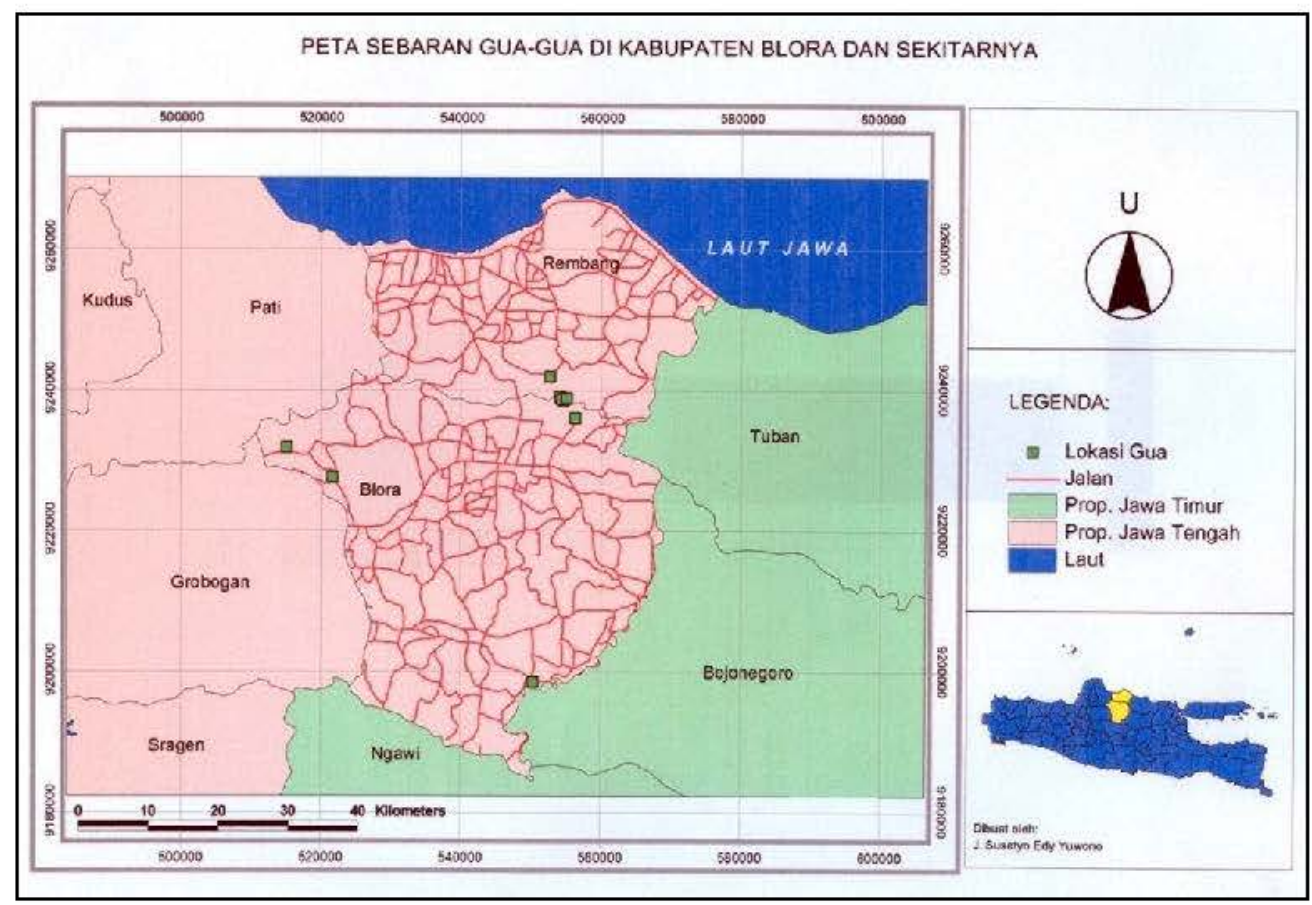

Peta sebaran gua-gua di Kabupaten Blora

Hasil survei tersebut kemudian ditindaklanjuti dengan ekskavasi pada gua terpilih, yaitu Gua Kidang sebagai satu-satunya gua yang memiliki indikasi hunian. Temuan permukaan dan hasil ekskavasi antara lain meliputi 
beberapa tipe alat dari cangkang moluska seperti serut, lancipan, penusuk, sudip, dan manik-manik/perhiasan; serta alat dari tulang seperti: sudip, lancipan, pengasah, dan spatula. Temuan berbagai jenis artefak tersebut merupakan bukti adanya penghunian manusia masa prasejarah yang cukup intensif di Gua Kidang (Nurani dan Yuwono, 2005).

Hasil ekskavasi pada tahun 2009 memperkuat kesimpulan tersebut dengan ditemukannya fragmen gigi dan tulang Homo sapiens yang mungkin pernah menghuni gua ini. Satu hal yang menarik perhatian dari berbagai temuan tersebut adalah belum ditemukannya artefak litik baik dari survei maupun ekskavasi. Kondisi demikian berbeda dengan temuan artefak dari gua-gua lainnya di Jawa, yang menunjukkan ciri budaya manusia penghuni gua antara lain adalah artefak cangkang moluska, tulang, dan batu/litik (Nurani, 2009). Nihilnya temuan artefak litik tersebut menarik untuk diungkap lebih lanjut, apakah memang penghuni gua kawasan karst Blora tidak mengenal peralatan litik ataukah bahan baku litik tidak tersedia di lingkungan sekitar kawasan karst Blora? Hal tersebut akan terjawab melalui kajian geologis yang dilakukan, terutama di kawasan karst Todanan tempat Gua Kidang berada.

\section{GEOLOGI KAWASAN KARST TODANAN, BLORA}

Secara geologis daerah Todanan termasuk dalam zona Rembang pada fisiografi Pulau Jawa (lihat peta lokasi penelitian). Batuan penyusun daerah ini terdiri atas batuan batu gamping berlapis, fragmental, berukuran 25-30 cm, semakin ke atas ketebalan per lapisan semakin tebal sampai 60 $\mathrm{cm}$, berwarna putih kecoklatan, pada bagian atas di beberapa tempat terdapat terumbu karang dan travertine. Selaras di bagian bawah satuan batuan ini berupa napal gampingan (silicified silt stone) yang agak kompak dan berwama abu-abu. Satuan batuan batu gamping tersebut merupakan penyusun Formasi Ledok, sedangkan napal sebagai penyusun batuan Formasi Wonocolo. Ciri-ciri yang dapat dikenali di lapangan, napal tampak kurang kompak berwarna abu-abu hingga abu-abu kekuningan. Material batuan penyusun di atas satuan batuan batu gamping adalah endapan sungai yang tersingkap di sekitar Sungai Kedungwungu, Sungai Kedungwaru, dan Sungai Jaten. Lapisan ini didominasi oleh material lepas. Endapan sungai terdiri dari fragmen-fragmen batu karst berukuran berangkal hingga bongkah berbentuk agak membundar hingga agak menyudut. Bongkah-bongkah batu gamping menyebar di sekitar hulu anak Sungai Kedungwungu, sedangkan yang berukuran berangkal terdapat pada sepanjang sungai ke hilir. Selain itu pula beberapa material lain terdiri dari rijang merah berukuran kerakal - berangkal, rijang kuning berukuran kerakal - berangkal, dan lempung silikaan yang berukuran berangkal, serta fragmen andesit berukuran berangkal - kerakal. Di atas satuan aluvial terdapat lapisan tanah hasil pelapukan batuan gamping yang berukuran lanau berwarna coklat kemerahan, agak liat dan menyebar pada kaki-kaki 


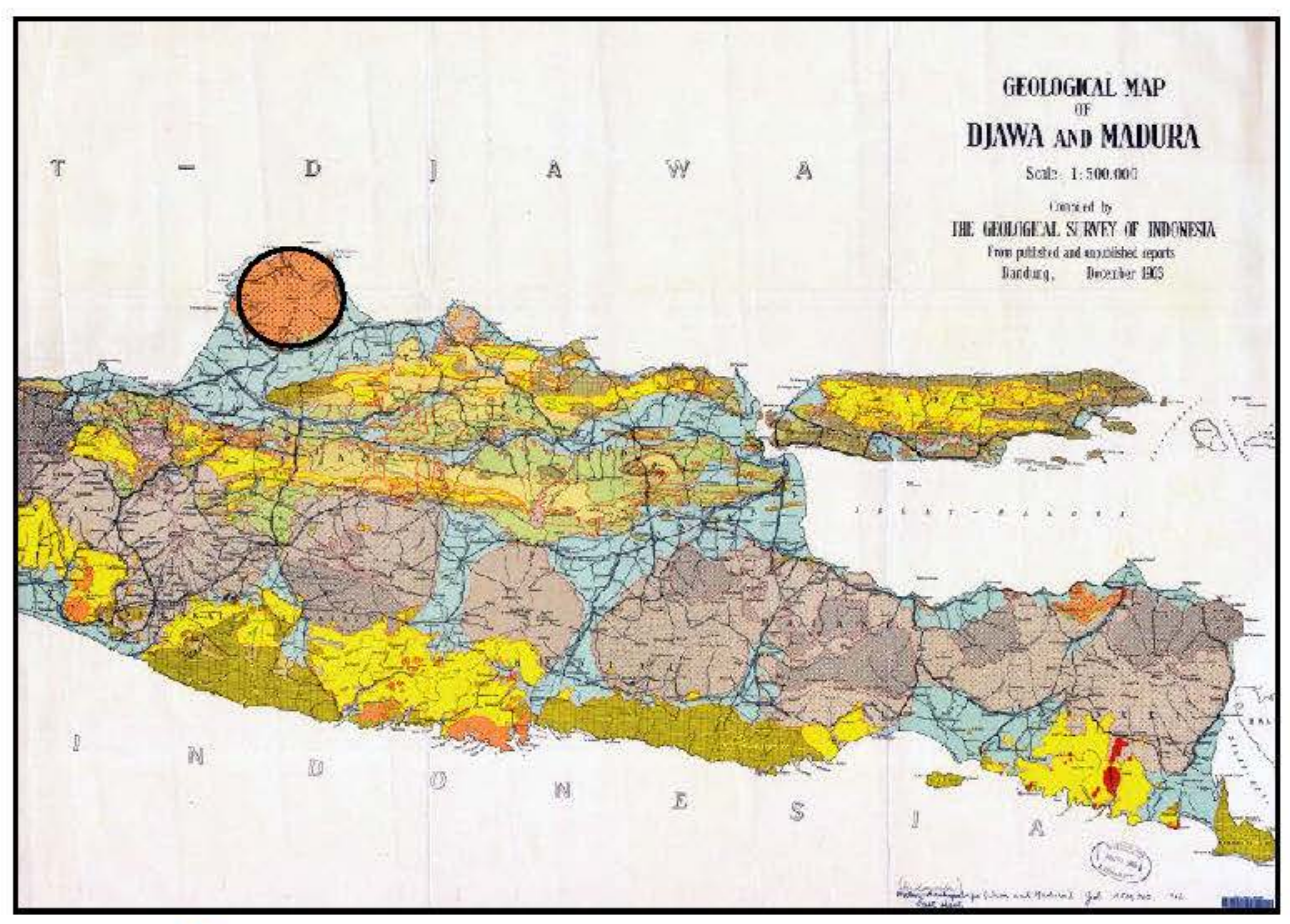

Peta Lokasi Penelitian pada Fisiografi sebagian Pulau Jawa

bukit. Satuan tanah ini sekarang dimanfaatkan oleh masyarakat untuk bercocok tanam padi.

Pada satuan batuan batugamping terdapat sejumlah gua sebagai bagian dari fisiografi sungai bawah tanah. Begitu pula di daerah Kedungwungu dan sekitamya banyak terdapat gua dan luweng. Salah satu di antaranya adalah Gua Kidang. Sungai-sungai bagian hulu merupakan stadia sungai dewasa dengan tebing yang cukup curam dan bentuk daerah aliran sungai mengikuti topografi di sekitarnya seperti terlihat pada DAS anak-anak Sungai Kedungwungu. Sungai induk Kedungwungu bertopografi landai dengan stadia dewasa. Sungai ini merupakan sungai yang berair sepanjang musim walaupun debit airnya kadang berkurang. Pada musim basah debit air besar dengan arus sungai deras, namun di musim kering, debit air berkurang dengan arus sungai lemah. Kondisi tersebut menyebabkan di beberapa tempat dapat berkembang biak moluska air tawar (pelecypoda dan gastropoda).

Kondisi geologi struktur yang terdapat di daerah ini dapat dilihat berupa patahan atau sesar turun. Bukti tersebut berada di lokasi Sungai Kalisat yang menunjukkan bagian selatan mengalami penurunan sedangkan bagian utara mengalami pengangkatan. Hal ini mempengaruhi proses genesa morfografi daerah Kedungwungu dan sekitarnya. Sebagaimana terlihat di daerah selatan, proses pembentukan tanah lebih cepat dibandingkan dengan bagian utara. Walaupun bagian selatan ini mengalami penurunan, pembentukan cekungan rawa atau danau tidak terjadi. Bukti yang tersingkap di sungai-sungai bagian selatan menunjukkan 
material endapan sungai langsung kontak dengan batuan induk. Artinya, tidak adanya lapisan lempung hitam menunjukkan daerah selatan tidak pernah menjadi bentukan rawa atau danau. Hal ini juga didukung oleh kondisi topografinya yang tidak memperlihatkan suatu perangkap air.

\section{HASIL EKSKAVASI DI GUA KIDANG}

Tujuan ekskavasi Gua Kidang adalah untuk mengetahui pola pemanfaatan lahan gua yang akan tercermin dari pola tata ruang gua. Ekskavasi dilakukan dengan membuka empat kotak gali. Sebelumnya seluruh lahan gua dibuat grid berukuran 1,5 x 1,5 m untuk masing-masing kotak dan garis sumbu grid dijadikan sebagai titik nol. Penamaan kotak disesuaikan arah mata angin searah jarum jam, sebagai contoh kotak U2T6 artinya dari titik 0 ke arah utara 2 dan ke arah timur 6 . Adapun keempat kotak ekskavasi yang digali dipilih pada bagian-bagian ruang tertentu dalam gua yang dianggap strategis. Kotak yang digali meliputi kotak T6S1 (bagian depan kanan mulut gua); S2B1 (bagian kanan tengah gua); S1B6 (bagian dalam kanan gua); dan B2U7 (bagian kiri tengah gua).

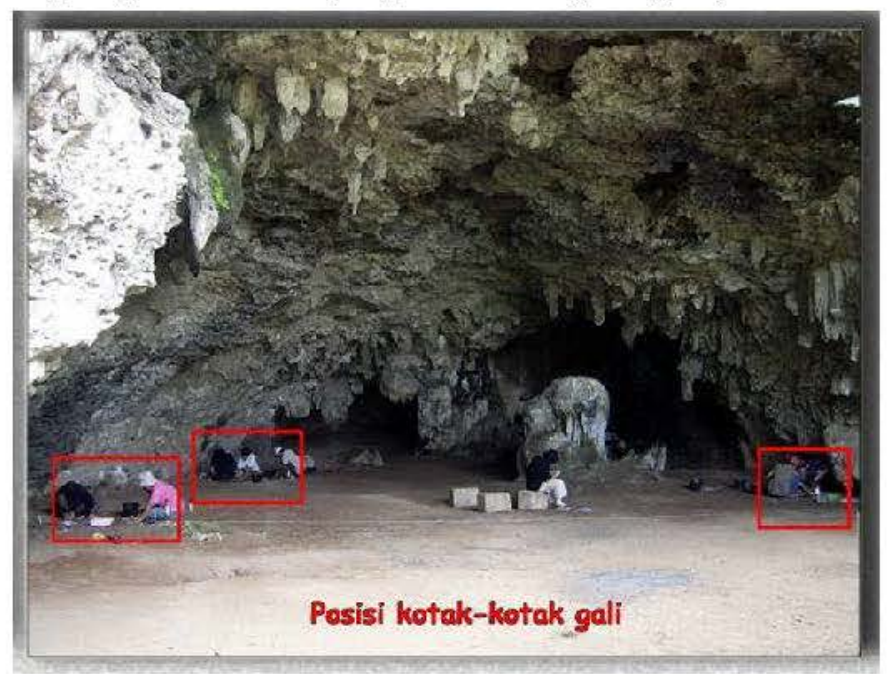

Ekskavasi pada tahun 2009 mencapai kedalaman sekitar $45 \mathrm{~cm}$ dari permukaan tanah (kecuali kotak T6S1 yang telah mencapai kedalaman 150 $\mathrm{cm}$ ). Pada masing-masing kotak ditemukan artefak maupun ekofak. Kotak T6S1 menghasilkan temuan artefak dari cangkang moluska dan tulang, dan sisa makanan (ekofak) baik tulang, gigi vertebrata maupun cangkang moluska laut dan air tawar. Fragmen tulang atau gigi Homo sapiens juga ditemukan. Di Kotak S2B1, pada lapisan awal, ditemukan keramik, tembikar, dan mata uang logam masa sejarah. Baru setelah mencapai lapisan ketiga, pada kedalaman $30 \mathrm{~cm}$ dari permukaan tanah, ditemukan berbagai tipe artefak dari cangkang moluska dan tulang. Sementara itu, di Kotak S1B6 sejak lapisan awal telah ditemukan berbagai variasi artefak dari 
cangkang moluska dan tulang. Adapun kotak B2U7 sampai pada kedalaman 30 masih banyak ditemukan tembikar dan keramik, serta mata uang logam masa sejarah. Pada lapisan selanjutnya, temuan didominasi oleh artefak cangkang moluska dan tulang. Selain itu, fragmen tulang dan gigi Homo sapiens juga ditemukan.

Selanjutnya hasil ekskavasi pada tahun 2010 yang melanjutkan tiga kotak ekskavasi tahun sebelumnya, yaitu T6S1, S1B6, dan B2U7, semakin tampak jelas mengungkap pola hidup pendukung Gua Kidang. Ekskavasi ketiga kotak uji masing-masing mencapai kedalaman $60 \mathrm{~cm}$ pada kotak S1B6, kedalaman $75 \mathrm{~cm}$ pada kotak B2U7, dan $160 \mathrm{~cm}$ pada kotak T6S1. Berbeda dengan temuan pada ekskavasi tahun 2009 yang didominasi temuan cangkang moluska, baik artefak maupun ekofak, ekskavasi tahun 2010 ini lebih didominasi dengan temuan fragmen tulang baik artefak maupun ekofak. Pada akhir penggalian kotak S1B6 ditemukan fragmen tulang berukuran relatif besar (species bovidae) yang terkonsentrasi pada satu konteks dengan artefak tulang. Kotak B2U7 selain didominasi fragmen tulang dan gigi binatang darat juga banyak ditemukan fragmen cranium, gigi, dan tulang lainnya dari Homo sapiens. Selain itu juga ditemukan beberapa artefak litik berupa alat pengasah dari bahan batu rijang merah, serta beberapa tembikar. Adapun temuan pada kotak T6S1 mengindikasikan sisa-sisa kubur yaitu dengan temuan susunan krakal batu gamping membujur baratlaut - tenggara yang tampak disusun secara sengaja. Pada penggalian tahun 2010 indikasi tersebut semakin tampak jelas yaitu dengan temuan tulang panjang bagian kaki Homo sapiens dalam posisi telungkup pada akhir penggalian dengan kedalaman $160 \mathrm{~cm}$ dari permukaan tanah. Namun demikian, belum dapat dipastikan apakah memang benar jejak kubur atau bukan mengingat tulang tersebut masih belum tersingkap seluruhnya. Temuan penting lainnya terdapat pada bagian utara kotak yang didominasi temuan artefak tulang berupa lancipan dan spatula bercampur dengan batu gamping berukuran krikil - krakal.

Hasil ekskavasi baik pada tahun 2009 maupun 2010 menunjukkan bahwa masing-masing kotak gali memiliki temuan relatif sama. Ketiga kotak gali T6S1, B2U7, dan S2B1 menunjukkan bahwa tinggalan budaya prasejarah mulai ditemukan pada kedalaman $30 \mathrm{~cm}$ dari permukaan tanah, sedangkan pada kotak S1B6 sudah ditemukan pada kedalaman $5 \mathrm{~cm}$. Hal tersebut dapat terjadi disebabkan karena permukaan tanah Gua Kidang cenderung semakin menurun pada bagian dalam gua. Adapun frekuensi temuan baik artefak maupun ekofak menunjukkan adanya perbedaan yang signifikan. Pada lapisan atas temuan lebih didominasi oleh fragmen cangkang moluska baik sebagai artefak maupun ekofak, sedangkan pada lapisan berikutnya temuan lebih didominasi oleh fragmen tulang dan gigi binatang darat atau vertebrata baik sebagai artefak maupun ekofak. Dari sejumlah temuan tersebut, yang paling menarik tentu adalah temuan artefak batu berupa alat pengasah, walaupun jumlahnya sedikit, dan gejala penguburan yang ditandai dengan susunan batu gamping berukuran krakal membujur baratlaut - tenggara. 


\section{POLA HIDUP PENGHUNI GUA KIDANG}

\section{Ruang Jelajah Manusia Penghuni Gua Kidang dalam Mengeksploitasi Lingkungan Alam Sekitarnya}

Sebagaimana telah diuraikan pada bahasan Geologi Kawasan Karst Todanan, tampak jelas terdapat hubungan antara lingkungan purba daerah ini dengan temuan arkeologis Gua Kidang. Temuan hasil ekskavasi Gua Kidang menunjukkan adanya pemanfaatan moluska air tawar dan binatang darat sebagai makanan dan peralatan. Analisis terhadap temuan ini akan dapat memberikan gambaran tentang (a) ruang jelajah manusia pendukung Gua Kidang dalam mengeksploitasi moluska air tawar, (b) kapan saja mereka mengeksploitasi moluska, serta binatang darat dan (c) bagaimana pengaruh sumber bahan terhadap perkembangan produksi perkakas.

Hasil survei geoarkeologi di daerah aliran Sungai Kedungwungu bagian hulu menunjukkan bahwa singkapan satuan batuan batugamping yang bercirikan fragmentaris, berlapis, dan travertine terdapat di beberapa permukaan. Satuan batuan ini menempati dan menyebar pada topografi perbukitan gamping dengan ketinggian $100-437,5 \mathrm{~m}$ dari permukaan laut. Kontak antara satuan batuan batugamping dengan material sedimen yang lebih muda di lokasi adalah berupa batas erosi antara batuan batugamping dengan fragmen endapan alluvial. Singkapan kontak ini juga ditemukan di bagian daerah aliran Sungai Kedungwungu di Desa Kedungwungu. Kondisi demikian membuktikan bahwa sejak pengangkatan daratan masa plioplestosen, lingkungan sungai terbentuk secara terus menerus tanpa mengalami penggenangan pembentukan rawa maupun danau. Selain itu, sungai-sungai yang terdapat di daerah ini berkembang dari stadia muda hingga stadia tua tanpa mengalami penggenangan.

Fluktuasi volume debit air sungai sangat dipengaruhi oleh keadaan musim. Musim penghujan debit air maupun arus air permukaan sangat tinggi sedangkan pada musim kemarau debit air maupun arus air permukaan sangat kecil bahkan beberapa anak sungai mengalami kekeringan. Air permukaan tidak pernah tergenang menjadi rawa maupun danau disebabkan oleh faktor batuan penyusun berupa batugamping fragmental yang membentuk aliran sungai bawah permukaan. Hal ini juga didukung dengan kenyataan tidak terdapatnya topografi perbukitan yang membentuk perangkap air permukaan. Kondisi tersebut menyebabkan air permukaan mengalir melalui anak-anak sungai yang bermuara di sungai induk dan terus berlanjut ke sungai-sungai utama lainnya. Lebih lanjut dapat dilihat peta geologi daerah Karangwungu di bawah. 


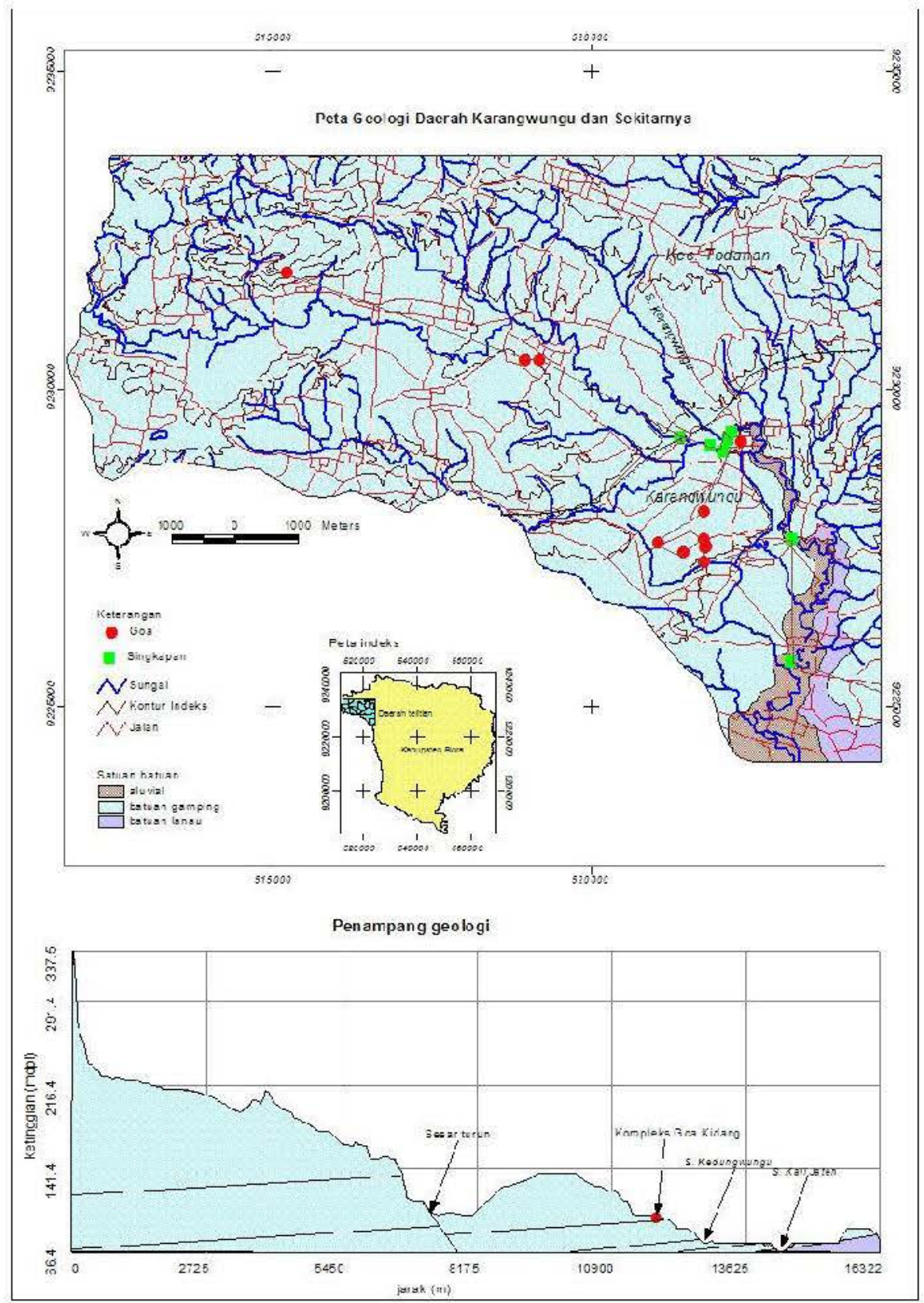

Kondisi geologis sebagaimana telah diuraikan di atas dapat memberi gambaran kapan manusia penghuni Gua Kidang mengeksploitasi moluska air tawar yaitu pada musim kering. Hal tersebut didasarkan pada kondisi air permukaan pada sungai utama cukup jemih dan arus air tidak deras. Pada kondisi tersebut pertumbuhan moluska sangat baik sehingga ketersediaan makanan bagi manusia pendukung Gua Kidang cukup besar. Di lain pihak, pada musim basah air permukaan di daerah aliran sungai mengalami peningkatan debit volume, arus cukup deras, dan air tampak keruh. Hal ini 
menyebabkan pertumbuhan moluska terganggu bahkan sama sekali tidak berkembang. Ketersediaan moluska mengalami penurunan. Namun, di sisi lain hewan vertebrata yang tinggal di hutan terbuka justru berkembang baik. $\mathrm{Hal}$ tersebut menunjukkan ketersediaan pangan bagi manusia pendukung Gua Kidang berubah berupa hewan-hewan vertebrata. Dengan kata lain ketersediaan sumber makanan bagi manusia penghuni Gua Kidang berbeda antara musim kering dengan musim basah.

Berbeda halnya dengan ketersediaan bahan baku alat litik. Dari penelitian diketahui di daerah penelitian tidak cukup tersedia bahan litik yang baik. Bahan alat litik biasanya memiliki sifat kekerasan di atas 6,5 skala mosh dengan pecahan yang konkoidal agar dapat membentuk tajaman. Jenis yang memiliki sifat tersebut antara lain adalah batu rijang, kuarsa, kalsedon, dan batuan silikaan lainnya yang tidak terdapat di daerah ini, kecuali hanya beberapa batuan silikaan berwarna merah dan kuning. Batuan yang sesuai untuk membuat alat ditemukan di sekitar aliran sungai Kedungwungu hingga Sungai Kali Jaten. Kondisi ini memberikan alasan mengapa alat litik tidak berkembang dengan baik. Meskipun demikian, temuan-temuan batuan silikaan di kompleks Gua Kidang menunjukkan bahan batuannya diperoleh dari sekitar aliran sungai permukaan.

\section{Karakter Budaya Gua Kidang}

Hasil ekskavasi pada keempat kotak gali di Gua Kidang, yang mencapai kedalaman rata-rata $75 \mathrm{~cm}$ dari permukaan tanah, menunjukkan gua ini merupakan tempat hunian yang intensif dimanfaatkan untuk aktivitas sehari-hari. Hasil ekskavasi menunjukkan temuan didominasi oleh artefak cangkang moluska dan tulang, sementara artefak litik baik dari temuan permukaan maupun ekskavasi sangat terbatas

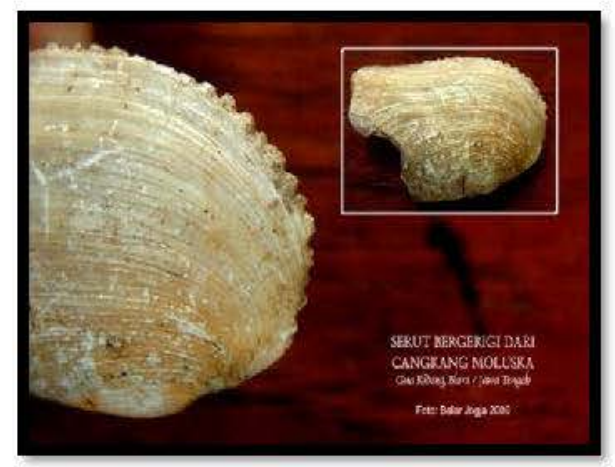

alat kerang multi fungsi: gergaji sekaligus serut

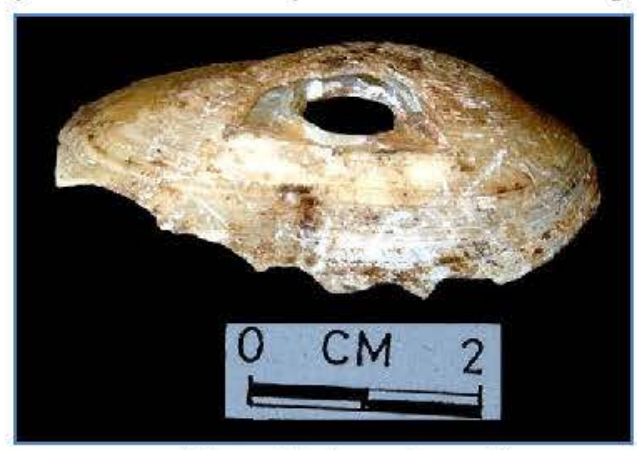

artefak multi fungsi: manikmanik/perhiasan sekaligus serut bergerigi

Temuan artefak cangkang moluska dari Gua Kidang memiliki peranan penting dalam mengungkap jejak budaya gua terutama di Jawa dalam pengembangan teknologi pembuatan peralatan dari cangkang moluska. Hal tersebut tampak jelas dari variasi tipologis peralatan yang secara teknologis dibuat secara lebih rumit dibandingkan artefak cangkang moluska temuan pada gua-gua lainnya di Jawa. Tipe alat-alat cangkang moluska yang ditemukan 
antara lain berupa serut, lancipan, dan manik-manik atau perhiasan. Bahan yang digunakan selain cangkang moluska klas pelecypoda juga cangkang moluska klas gastropoda yang belum pernah ditemukan di gua-gua lainnya di Jawa.

Temuan penting lainnya adalah artefak tulang yang menunjukkan teknik pengerjaan yang relatif tinggi dibandingkan dengan temuan artefak dari gua-gua lainnya di Jawa (Nurani, 2009). Tipe alat tulang yang ditemukan di Gua Kidang sebagian besar berupa lancipan, pengasah, dan spatula. Tipe lancipan merupakan alat tulang yang dominan baik berukuran pendek $(2-3 \mathrm{~cm})$, sedang $(5-7 \mathrm{~cm})$, maupun panjang (lebih dari $7 \mathrm{~cm}$ ). Teknik pengerjaan juga bervariasi dari yang sederhana, yaitu sekedar membuat pangkasan dua arah untuk membentuk lancipan, hingga teknik yang rumit yaitu pengerjaan sekunder melalui retus pada bagian tajaman, pembakaran untuk memperkuat tulang, dan pembentukan tangkai. Adapun artefak litik meskipun minim, namun menunjukkan tipe alat yang berbeda dengan temuan artefak litik di gua-gua Jawa umumnya, yaitu berupa alat pengasah yang dapat digunakan untuk mengasah alat-alat dari tulang dan cangkang moluska.

Ciri budaya lain yang cukup menonjol, selain perkembangan teknologi pembuatan peralatan dari cangkang moluska dan tulang, adalah jejak penguburan. Berdasarkan hasil

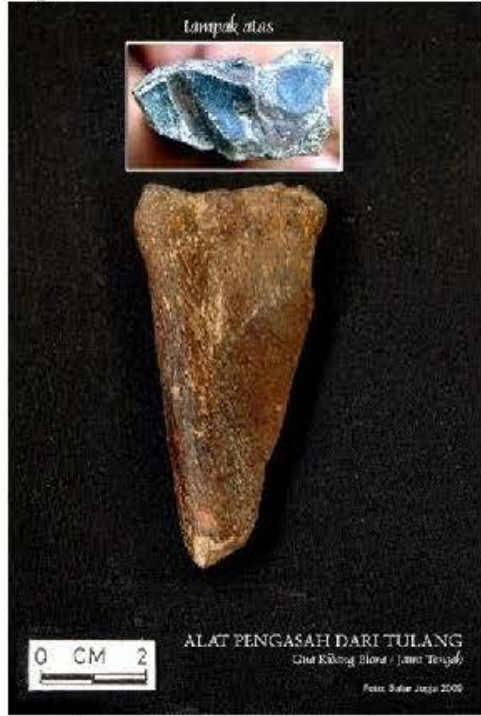

alat pengasah dari tulang ekskavasi sebagaimana diuraikan di atas, temuan sisa-sisa rangka Homo sapiens ditemukan pada 2 (dua) kotak gali yaitu kotak T6S1 dan B2U7. Pada kedua kotak gali ini banyak ditemukan fragmen cranium, gigi, maupun tulang Homo sapiens sejak pada kedalaman $40 \mathrm{~cm}$ dari permukaan tanah. Sementara itu, indikasi kubur tampak jelas dengan ditemukannya bongkahan batu gamping yang disusun membujur baratlaut - tenggara. Susunan batu gamping seperti ini biasanya merupakan batu penimbun mayat (Simanjuntak, 1999). Hingga akhir penggalian tahun 2010 data kubur belum tuntas terungkap, meskipun telah ditemukan tulang panjang bagian

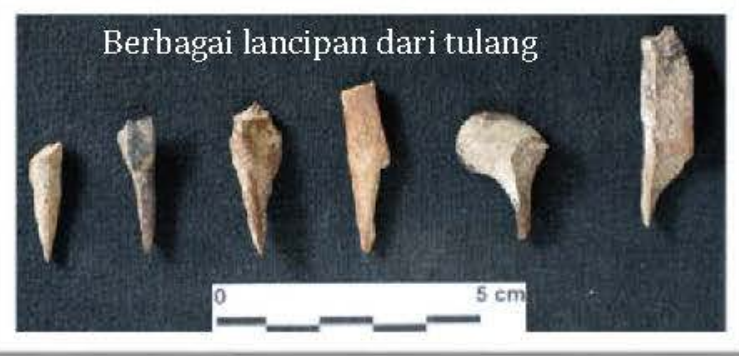

Berkala Arkeologi Tafiun XXXX Edisi YNo. 1/Mei 2010 kaki dalam posisi telungkup pada kotak T6S1 kedalaman $160 \mathrm{~cm}$ dari permukaan tanah. Adapun indikasi kubur pada kotak B2U7 selain susunan bongkahan batu gamping juga ditemukan fragmen cranium dan gigi Homo sapiens dalam jumlah relatif banyak. 


\section{KESIMPULAN}

Berdasarkan uraian di atas, dapat dikemukakan beberapa simpulan sementara yang telah dapat diperoleh dari hasil penelitian di situs Gua Kidang dan lingkungan sekitamya.

1. Gua Kidang merupakan satu-satunya gua hunian masa prasejarah di kawasan karst Blora. Dari data geoarkeologi yang didapat, dapat diketahui manusia pendukung Gua Kidang beradaptasi terhadap kondisi lingkungan alam sekitamya dengan melakukan penjadwalan perolehan makanan mengikuti musim tertentu. Paleoekologi kawasan karst Gua Kidang menunjukkan terdapat perbedaan mencolok antara musim basah dengan musim kering. Perbedaan musim tersebut berpengaruh terhadap ketersediaan sumber makanan. Pada musim basah banyak tersedia binatang-binatang vertebrata, sedangkan pada musim kering berlimpah ketersediaan binatang-binatang invertebrata yaitu moluska baik klas pelecypoda maupun gestropoda air tawar dan darat. Selain itu, tampak jelas teknologi litik atau alat batu tidak berkembang di kawasan ini karena ketiadaan sumber bahan.

2. Hasil ekskavasi di Gua Kidang menunjukkan terdapat perbedaan dominasi jenis temuan yang signifikan pada lapisan budayanya. Pada lapisan bawah, temuan didominasi oleh fragmen tulang baik sebagai artefak (alat atau perhiasan) maupun ekofak (sisa makanan). Sementara itu pada lapisan atas, temuan lebih didominasi dengan cangkang moluska baik sebagai artefak maupun ekofak. Pola sebaran temuan yang berbeda antarlapisan tanah tersebut memperkuat kesimpulan butir pertama yaitu penghuni pendukung Gua Kidang telah mengenal penjadwalan musim dalam mengekplorasi sumber pangan. Pada musim kering, mereka lebih banyak mengeksplorasi hewan invertebrata atau moluska dan siput, sementara pada musim basah mengeksplorasi binatang vertebrata.

3. Dari segi perkembangan teknologi, baik pembuatan peralatan maupun perhiasan dari tulang, cangkang moluska, serta sedikit batu rijang merah, komunitas penghuni gua Kidang terbukti telah memilki teknologi yang lebih maju dibandingkan penghuni gua-gua prasejarah umumnya di Jawa. Perkembangan teknologi dalam pembuatan peralatan (serut dan lancipan) dan manik-manik dari cangkang moluska menunjukkan pengerjaan sekunder yang lebih detil melalui pembuatan retus-retus. Selain itu, bahan yang digunakan tidak hanya dari klas pelecypoda saja namun juga dari klas gastropoda yang selama ini belum pernah ditemukan di gua-gua lainnya di Jawa. Kemajuan teknologi dalam pembuatan alat dan perhiasan dari tulang yang meliputi jenis lancipan, spatula, pengasah, dan perhiasan tampak dari adanya pembakaran dan pengerjaan yang lebih rumit dibandingkan peralatan dari tulang yang ditemukan di gua-gua lainnya di Jawa. Teknik pengerjaan sekunder tampak jelas terlihat perkembangannya terutama pada lancipan, sedangkan pengerjaan untuk perhiasan antara lain dikerjakan dengan 
pengeboran atau pembuatan lubang yang kemungkinan digunakan sebagai bandul atau liontin.

4. Temuan sisa sisa tulang Homo sapiens dalam jumlah cukup banyak terutama berupa fragmen cranium dan gigi menunjukkan kemungkinan adanya penguburan. Hal ini didukung dengan temuan berupa susunan bongkahan batu gamping berorientasi baratlaut - tenggara yang biasa menjadi penimbun rangka manusia. Indikasi tersebut ditemukan pada dua kotak gali dengan kedalaman yang berbeda yaitu kotak B2U7 pada kedalaman $60 \mathrm{~cm}$ dari permukaan tanah sedangkan kotak T6S1 pada kedalaman $155 \mathrm{~cm}$. Namun demikian, sampai akhir penggalian data kubur belum tersingkap seutuhnya mengingat sebagian masih terpendam dalam tanah.

\section{KEPUSTAKAAN}

Clarke, 1977. Spatial Information in Archaeology, in Spatial Archaeology. London: Academic Press, pp. 1-23

Heekeren, H.R. van., 1972. "Stone Age of Indonesia", VKI, The Hague: Martinus Nijhoff.

Mundardjito, 1990. "Metode Penelitian Permukiman Arkeologi", Monumen Lembaran Sastra Seri Penerbitan IImiah No. 11 Edisi Khusus, Depok: Fakultas Sastra UI. HIm. $19-31$.

Nurani, Indah Asikin, 1999, LPA Pola Pemanfaatan Lahan Gua-gua di Kabupaten Bojonegoro, Yogyakarta: Balai Arkeologi, tidak terbit.

2000, LPA Pola Pemanfaatan Lahan Gua-gua di Kabupaten Ponorogo, Yogyakarta: Balai Arkeologi, tidak terbit.

2006 "Pemanfaatan Lahan Gua di Jawa" dalam Permukiman di Indonesia: Perspektif Arkeologi. Jakarta: Pusat Penelitian dan Pengembangan Arkeologi Nasional. HIm: 51-62

2009 LPA Pola Okupasi Gua Hunian Prasejarah Kawasan Karst Blora Tahap III. Yogyakarta: Balai Arkeologi, tidak terbit.

Nurani, Indah Asikin dan Agus Tri Hascaryo, 2000, "Pola Pemanfaatan Lahan Gua Komunitas Gunung Watangan", Berita Penelitian Arkeologi No. 16. Yogyakarta: Balai Arkeologi 
Nurani, Indah Asikin dan J. Susetyo Edy Y, 2005. LPA Pola Okupasi Guagua Hunian Prasejarah Kawasan Pegunungan Utara Jawa di Kabupaten Blora Tahap I. tidak terbit

2008 "Gua Kidang, Pilihan Manusia Prasejarah di Kawasan Karst Blora" dalam Berkala Arkeologi Tahun XXVIII Mei. Yogyakarta: Balai Arkeologi. HIm: 1-20

Simanjuntak, H Truman, 1999. "Budaya Awal Holosen di Gunung Sewu". Berkala Arkeologi th XIX Edisi no. 1/Mei. Yogyakarta: Balai Arkeologi

-_-_-_, 1980. Laporan Arkeologis Penelitian Paleo-Antropologi Ngandong. Yogyakarta: Balai Arkeologi

Soebroto, Ph, 1983. "Studi Tentang Pola Permukiman Arkeologi: Kemungkinan Penerapannya di Indonesia". PIA III. Jakarta: Proyek Penelitian dan Purbakala, hlm. 1176 - 1186

Soejono, R.P., 1984. Sejarah Nasional Indonesia Jilid 1. Jakarta: Balai Pustaka. 